\title{
HUBUNGAN KARAKTERISTIK SOSIAL EKONOMI PETANI DENGAN PENDAPATAN USAHATANI SEMANGKA (Suatu Kasus di Desa Cikadu Kecamatan Cikalong Kabupaten Tasikmalaya) \\ THE RELATIONSHIP OF SOCIAL ECONOMIC CHARACTERISTICS OF FARMERS WITH WATERMELON BUSINESS INCOME (A Case in Cikadu Village, Cikalong District, Tasikmalaya Regency)
}

\author{
Fitri Awaliyah*", Ane Novianty ${ }^{2}$ \\ ${ }^{1}$ Program Studi Agribisnis Universitas Garut, Jl. Raya Samarang No 52 A Garut \\ ${ }^{2}$ Program Studi Agribisis Universitas Galuh, J1 R. E. Martadinata No.150 Ciamis \\ *E-mail: fitriawaliyah@uniga.ac.id \\ (Diterima 26-12-2021; Disetujui 22-01-2022)
}

\begin{abstract}
ABSTRAK
Tujuan penelitian ini adalah untuk menganalisis hubungan sosial ekonomi petani yang terdiri atas umur, pengalaman berusahatani dan luas lahan terhadap pendapatan usahatani buah semangka. Penelitian dilakukan di Desa Cikadu Kecamatan Cikalong Kabupaten Tasikmalaya. Jenis penelitian ini merupakan penelitian asosiatif dengan pendekatan kuantitatif. Teknik penarikan sampel dalam penelitian ini menggunakan teknik sensus, dengan mengambil 10 petani yang terus menerus membudidayakan buah semangka dalam satu tahun. Teknik analisis data menggunakan analisis korelasi Pearson dengan menggunakan software SPSS. Hasil penelitian menunjukkan bahwa umur mempunyai hubungan yang kuat dengan pendapatan. Tetapi pengalaman usahatani pada kasus penelitian ini mempunyai hubungan negatif dengan tingkat pendapatan. Sedangkan luas lahan mempunyai hubungan yang sangat kuat dengan tingkat pendapatan petani buah semangka.
\end{abstract}

Kata kunci: Faktor Sosial Ekonomi, Petani, Pendapatan, Semangka

\section{ABSTRACT}

The purpose of this study was to analyze the socio-economic relationship of farmers consisting of age, farming experience and land area to watermelon farming income. The research was conducted in Cikadu Village, Cikalong District, Tasikmalaya Regency. This type of research is an associative research with a quantitative approach. The sampling technique in this research uses the census technique, by taking 10 farmers who continuously cultivate watermelons in one year. The data analysis technique used Pearson correlation analysis using SPSS software. The results showed that age had a strong relationship with income. But the experience of farming in the case of this study has a negative relationship with the level of income. Meanwhile, land area has a very strong relationship with the income level of watermelon farmers.

Keywords: Socio-Economic Factors, Farmers, Income, Watermelon

\section{PENDAHULUAN}

Usahatani komoditas semangka merupakan usahatani yang ckup menjanjikan dan memberikan keuntungan cukup tinggi untuk petani. Hasil penelitian mengenai pendapatan usahatani semangka di Kabupaten Sigi (Juprin, 2016) menunjukkan bahwa hasil $\mathrm{R} / \mathrm{C}$ rasionya adalah sebesar 3,3 dengan besaran pendapatan rata-rata Rp15.730.998/ Ha/MT. Tidak hanya di daerah Kabupaten Sigi saja, hasil 


\section{HUBUNGAN KARAKTERISTIK SOSIAL EKONOMI PETANI \\ DENGAN PENDAPATAN USAHATANI SEMANGKA \\ Fitri Awaliyah, Ane Novianty}

penelitian di Kabupaten Rokan Hulu (Gunawan, 2014) menunjukkan bahwa usahatani semangka mempunyai hasil $\mathrm{R} / \mathrm{C}$ rasio sebesar 3,9 dengan pendapatan bersih senilai Rp18.544.153/Ha/MT. Di daerah Situbondo hasil usahatani semangka memberikan $\mathrm{R} / \mathrm{C}$ rasio cukup tinggi juga yaitu sebesar 2,08 dengan pendapatan sebesar Rp9.089.470/Ha/MT (Edi Musleh, 2019). Melihat potensi ekonomi yang didapatkan dari hasil usahatani buah semangka cukup tinggi, petani di Desa Cikadu Kecamatan Cikalong Kabupaten Tasikmalaya mengembangkan budidaya semangka hingga 3 kali tanam dalam satu tahun. Di Kecamatan Cikalong sendiri menurut data Dinas Pertanian Kabupaten Tasikmalaya tahun 2020, luas lahan panen yang digunakan untuk budidaya buah semangka mencapai 25 Hektar dengan tingkat produksi sebesar 159 Ton.

Pendapatan yang dihasilkan akan lebih optimal apabila petani mengalokasikan berbagai sumber daya yang dimiliki. Dalam usahatani sendiri sumberdaya yang dimanfaatkan sebagai faktor produksi antara lain tanah dan sumber daya alam, tenaga kerja, modal dan teknologi. Pada sisi lain, dalam memanfaatkan faktor produksi tersebut dibutuhkan kemampuan dan keterampilan untuk mengaturnya agar usahtani yang dibudidayakan mampu berjalan secara efektif dan efisien.

Keterampilan petani dalam mengolah sumberdaya bertani akan berpengaruh dari karakteristik yang dimiliki oleh petani tersebut. Karakteristik petani dan kompetensi usahatani merupakan gambaran kemampuan petani dalam mengelola usahatani berdasarkan perencanaan. Karakteristik petani dan kompetensi usahatani menunjukan kinerja dan tanggung jawab petani dalam menjalankan usahatani secara lebih baik dan berkesinambungan. Menurut Caragih (2013), bahwa karakteristik merupakan ciri atau karakteristik alamiah yang melekat pada diri seseorang yang meliputi umur, tingkat pendidikan, luas lahan, dan pengalaman yang dimiliki untuk berusaha tani. Penelitian ini bertujuan untuk menganalisis hubungan karakteristik sosial ekonomi yang terdiri atas umur, pengalaman dan luas lahan petani terhadap pendapatan usaha tani buah semangka di Desa Cikadu Kecamatan Cikalong Kabupaten Tasikmalaya. 


\section{METODE PENELITIAN}

Penelitian ini dilakukan di Desa Cikadu Kecamatan Cikalong Kabupaten Tasikmalaya, penentuan tempat penelitian tersebut dilakukan secara purposive sampling dengan pertimbangan bahwa Desa Cikadu merupakan sentra budidaya semangka di Kecamatan Cikalong. Peneltian dilakukan pada Bulan Februari hingga April 2021.

Jenis penelitian ini adalah penelitian asosiatif dengan menggunakan pendekatan kauntitatif. Penelitian asosiatif merupakan penelitian yang bertujuan untuk mengetahui hubungan dua variabel atau lebih (Sugiyono, 2012).

Teknik penarikan sampel dalam penelitian ini menggunakan teknis sensus. Jumlah sampel yang digunakan dalam penelitian ini adalah 10 orang yang diambil secara sensus karena jumlah populasi petani semangka di Desa Cikadu yang melakukan usahatani semangka secara terus menerus setiap tahun berjumlah 10 orang.

Rancangan analisis data pada penelitian ini menggunakan metode korelasi pearson, metode ini digunakan untuk melihat seberapa besar hubungan karakteristik sosial ekonomi petani terhadap pendapatan petani. Analisis data menggunakan alat bantu SPSS, dengan rumus matematis sebagai berikut :

$$
r=\frac{n \sum X Y-\sum X \cdot \sum Y}{\sqrt{\sqrt{n \sum X^{2}}-\left(\sum X^{2}\right)\left(n \sum Y^{2}-\left(\sum Y\right)^{2}\right.}}
$$

Dimana :

$\begin{array}{lll}\mathrm{r} & = & \text { nilai signifikansi }(0-1) \\ \mathrm{n} & = & \text { jumlah sample } \\ \mathrm{X} & = & \text { variabel bebas } \\ \mathrm{Y} & = & \text { variabel terikat }\end{array}$

Pada penelitian ini variabel besar merupakan variabel karakteristik sosial ekonomi petani yang terdiri atas umur, pengalaman dan luas lahan yang dipunyai oleh petani semangka. Sedangkan variabel terikat dalam peneltian ini adalah pendapatan yang dihasilkan oleh petani dari hasil budidaya komoditas buah semangka. Menurut Sugiyono (2007), pedoman interpretasi koefisien korelasi dapat digambarkan dalam tabel sebagai berikut:

Tabel 1. Pedoman Interpretasi Koefisien Korelasi R Interpretasi

\begin{tabular}{cc}
\hline $\mathbf{R}$ & Interpretasi \\
\hline $0,00-0,25$ & Sangat rendah \\
$0,26-0,50$ & Cukup \\
$0,51-0,75$ & Kuat \\
$0,76-0,99$ & Sangat Kuat \\
\hline
\end{tabular}


HASIL DAN PEMBAHASAN

\section{a. Karakteristik Sosial Ekonomi Petani}

\section{Umur}

Hasil survey lapangan terhadap responden memberikan gambaran mengenai umur petani. Di Desa Cikadu dari 10 petani yang mengusahakan buah semangka rata-rata berumur 47,5 tahun, dengan variasi umur petani paling rendah adalah 30 tahun dan paling tinggi mencapai 61 tahun. Menurut (Talumingan \& Habaludin, 2011) menerangkan bahwa produktivitas kerja dan pengambilan keputusan banyak dipengaruhi oleh umur petani. Namun jika dilihat dari fisik, semakin tua umur petani maka semakin berkurang kinerjanya.

\section{Pengalaman}

Rata-rata pengalaman para petani dalam mengusahakan buah semangka adalah 5,4 tahun. Dengan pengalaman bertani terpendek selama 2 tahun, dan pengalaman terlama yaitu selama 8 tahun dalam membudidayakan buah semangka ini. Pengalaman ini biasanya berkaitan erat dengan keterampilan petani dimana semakin lama pengalaman maka petani semakin terampil dalam budidaya dan mengelola usahatani.

\section{Luas Lahan}

Lahan yang dipunyai oleh petani merupakan modal utama untuk menanam buah semangka dan membudidayakannya. Lahan yang digunakan oleh para petani responden merupakan lahan sewa, mereka menyewa tanah Negara. Luas lahan garapan yang dikelola petani responden berbeda-beda luasannya, dengan lahan garapan terkecil 0,59 Hektar dan luas garapan terbesar adalah seluas 1 Hektar. Rata-rata para petani menggarap lahan sebesar 0,819 Hektar.

\section{Pendapatan}

Pendapatan dari hasil usahatani buah semangka, memiliki hasil yang bervariasi yang sangat tergantung dari luas lahan yang petani miliki. Namun secara umum, pendapatan untuk 1 Hektar pembudidayaan buah semangka ini menghasilkan pendapatan sekitar Rp19.000.000 . Nilai pendapatan para petani paling rendah yaitu $\mathrm{Rp}$ 13.905.473, pendapatan ini menjadi rendah karena petani mengusahkannya di luasan lahan 0,59 Hektar.

\section{b. Hubungan Umur dengan Pendapatan Usahatani}

Hasil analisis korelasi pada Tabel 2 menunjukkan bahwa karakteristik umur petani mempunyai tingkat korelasi yang 
kuat dengan tingkat pendapatan usahatani buah semangka dengan koefisien korelasi $\mathrm{r}$ adalah 0,584 . Hal tersebut menandakan bahwa rata-rata umur petani yang menjadi responden masih mempunyai tingkat kinerja yang baik untuk melakukan usahatani buah semangka ini. Rata-rata umur petani yang menjadi responden berkisar antara 30 hingga 61 tahun. Umur produktif seseorang berada pada angka 15 hingga 64 tahun. Sehingga usia range dari 30-61 tahunmasih berada pada usia produktif pada umumnya. Hasil analisis korelasi tersebut sama hasilnya dalam penelitian (Yogi Rosdiawan, 2016) yang menunjukkan bahwa umur memiliki hubungan positif dengan pendapatan.

Tabel 2. Hasil Analisis SPSS Hubungan Umur, Pengalaman, dan Luas lahan terhadap Pendapatan

\begin{tabular}{llrrrr}
\hline & & Umur & Pengalamn & Luas Lahan & Pendapatan \\
\hline Umur & Pearson Correlation & 1 & -047 & -643 & .584 \\
& Sig (2-tailed) & & .897 & .045 & .076 \\
& $\mathrm{~N}$ & 10 & 10 & 10 & 10 \\
\hline Pengalaman & Pearson Correlation & -047 & 1 & -641 & -774 \\
& Sig (2-tailed) & .897 & & .046 & .009 \\
& $\mathrm{~N}$ & 10 & 10 & 10 & 10 \\
\hline Luas Lahan & Pearson Correlation & .643 & -641 & 1 & .935 \\
& Sig (2-tailed) & .045 & .046 & 10 & .000 \\
& $\mathrm{~N}$ & 10 & 10 & .935 & 10 \\
\hline Pendapatan & Pearson Correlation & .584 & -774 & .000 & 1 \\
& Sig (2-tailed) & .076 & .000 & 10 & 10 \\
& $\mathrm{~N}$ & 10 & 10 & & 10 \\
\end{tabular}

Sumber : Data Primer Diolah, 2021

\section{c. Hubungan Pengalaman dengan Pendapatan Usahatani}

Hasil analisis korelasi pengalaman dengan pendapatan usahatani buah semangka pada Tabel 2 menunjukkan hasil koefisien korelasi -.0,774. Hasil tersebut memberikan gambaran bahwa pada kasus penelitian ini pengalaman berusahatani berkorelasi negatif dengan pendapatan. Hal ini terjadi karena petani responden mempunyai pengalaman berusahatani buah semangka rata-rata hanya 5,4 tahun, dengan variasi pengalaman 3 hingga 8 tahun. Hal tersebut menandakan bahwa para petani responden masih belum cukup lama dalam membudidayakan buah semangka namun meskipun begitu pendapatan yang dihasilkan cukup tinggi, dimana hasil pendapatan usahatani semangka ini ratarata mencapai Rp19.481.119/Ha/MT. Satu sisi lain semakin lama pengalaman 
usahatani berkaitan dengan umur responden yang kurang produktif. sehingga responden dengan pengalaman yang lama cenderung menggunakan tenaga kerja lebih banyak dalam usahataninya. Adapun hasil penelitian lain mengungkapkan bahwa lamanya pengalaman usahatani padi mempunyai hubungan yang lemah dengan pendapatan yang dihasilkanya (Panjaitan, Hasyim, \& Emalisa, 2013).

\section{d. Hubungan Luas Lahan dengan Pendapatan Usahatani}

Hasil analisis korelasi luas lahan dengan pendapatan usahatani buah semangka pada Tabel 2 menunjukkan koefisien korelasi 0,935 . Hal tersebut menunjukkan bahwa adanya hubungan keeratan yang sangat kuat antara luas lahan dengan pendapatan usahatani buah semangka di Desa Cikadu ini. Faktor produksi lahan merupakan faktor utama dala usahatani sehingga luas lahan yang besar akan memeberikan hasil pendapatan yang tinggi. Hasil analisis ini sama dengan hasil penelitian yang dilakukan oleh (Yogi Rosdiawan, 2016) yang menunjukkan bahwa luas lahan garapan usahatani padi mempunyai hubungan positif terhadap pendapatan petani di Desa Tanjungsari Kecamatan Rajadesa Kabupaten Ciamis.

\section{KESIMPULAN DAN SARAN}

\section{Kesimpulan}

Hasil penelitian memberikan kesimpulan bahwa karakteristik sosial ekonomi petani yang mengusahakan buah semangka di Desa Cikadu Kecamatan Cikalonng memberikan hasil yaitu umur mempunyai hubungan yang kuat terhadap tingkat pendapatan, sedangkan pengalaman mempunyai hubungan negative terhadap pendapatan dan luas lahan mempunyai hubungan sangat kuat terhaadap tingkat pendapatan petani.

\section{Saran}

Petani diharapkan menginisiasi terbentiknya kelompok tani penghasil buah semangka di Desa Cikadu, agar bisa memberikan wadah untuk berdiskusi, saling bertukar informasi dan pengetahuan terkait pembudidayaan dan sistem pemasaran buah semangka.

\section{DAFTAR PUSTAKA}

Dinas Pertanian Tasikmalaya (2020). Luas Panen, Produksi dan Produktivitas Semangka di Kecamatan Cikalong Kabupaten Tasikmalaya. Tasikmalaya: Dinas Pertanian Kabupaten Tasikmalaya.

Edi Musleh, A. M. (2019). Analisis Kelayakan Usahatani Semangka (Studi Kasus di Desa Jangkar, Kecamatan Jangkar Kabupaten Situbondo). Agribios, 65-71. 
Gunawan, I. (2014). Analisi Pendapatan Usahatani Semangka (Citrullus Vulgaris)di Desa Rambah Muda Kecamatan Rambah Hilir Kabupaten Rokan Hilir . Sungkai, 52-63.

Juprin, F. (2016). Analisis Pendapatan dan Kelayakan Usahatani Semangka di Desa Maranatha Kecamatan Sigi Biromaru Kabupaten Sigi. Agritekbis, 343349.

Panjaitan, A., Hasyim, H., \& Emalisa. (2013). Hubungan Karakteristik Sosial Ekonomi dengan Pendapatan Usahatani Padi Sawah Sistem Tanam Legowo 4:1. Journal on Social Economic of Agriculture and Agribusiness.
Sugiyono. (2007). Metode Penelitian Kuantitatif Kualitatifdan $R \& B$. Bandung: Alfabeta.

Sugiyono. (2012). Metode Penelitian Kuantitatif Kualitatifdan $R \& B$. Bandung: Alfabeta.

Talumingan, C., Kaunang, R. dan Habaludin, R. 2011. Analisis Pendapatan Usahatani Tomat di Desa Tonsewer Kecamatan Tompaso Kabupaten Minahasa. ASE, 7(3): 43-51.

Yogi Rosdiawan, D. H. (2016). Hubungan Faktor Sosial Ekonomi Petani dengan Pendapatan Usaha Tani Padi (Oriza sativa L) (Suatu Kasus di Desa Tanjungsari Kecamatan Rajadesa Kabupaten Ciamis). Agroinfo Galuh, 201-205. 